\title{
STABLE ISOTOPES (H, C, S) AND THE ORIGIN OF BALTIC AMBER
}

\author{
ALGIRDAS GAIGALAS ${ }^{1}$ and STANISLAW HALAS ${ }^{2}$ \\ ${ }^{l}$ Department of Geology and Mineralogy, Vilnius University, \\ M. K. Čiurlionio, 21/27, LT-03101 Vilnius, Lithuania \\ ${ }^{2}$ Mass Spectrometry Laboratory, Institute of Physics, Maria Curie-Skłodowska University, \\ Plac Marii Curie-Sktodowskiej 1, 20-031 Lublin, Poland
}

Received 18 April 2008

Accepted 15 September 2008

\begin{abstract}
New results of isotope analysis of light elements (H, C and S) of a dozen Baltic amber samples are described and discussed. Carbon isotope composition was nearly constant (ca. $-23 \%$ ), whereas sulphur and hydrogen varied in their isotope compositions from +4 to $-28 \%$ and from -171 to $-213 \%$, respectively. The formation and subsequent evolution of this material since its origin in $\mathrm{Pa}-$ leogene time until present is outlined.
\end{abstract}

Keywords: amber, H, C, S stable isotopes, Baltic Sea, origin.

\section{INTRODUCTION}

Amber is found throughout the world. The largest and most significant deposits occur along the shores of the Baltic Sea in Paleogene sands 40 to 60 million years old (Kosmowska-Ceranowicz, 2005). Amber bearing sediments have been formed in a river delta, which flowed from Scandinavia to the Sambian delta of the Eridanus River (Kasiński and Tołkanowicz, 1999; Lukashina and Kharin, 1999). In the river delta, amber resins accumulated in anaerobic conditions, matured and transformed into amber during millions of years. In this way, the primary amber bearing deposits were formed in the Kaliningrad Sambian peninsula. The primary deposits were occasionally eroded and the amber distributed by lagoon currents in southeastern areas in winter, as well as in the north-western direction in summer. Amber was carried by streams over large distances from its place of deposition and formed secondary accumulations in Poland, Germany, Denmark, Belarus and the Ukraine (Fig. 1). This amber is a placer mineral.

Baltic amber is a fossil tree resin that has achieved a stable state through loss of volatile constituents and chemical alteration after burial in the ground (Kosmowska-Ceranowicz, 2006). Studies showed that Baltic

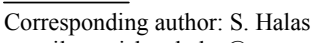

e-mail: stanislaw.halas@poczta.umcs.lublin.pl amber found in Sambian (Samland, now Kaliningrad district of Russia) was actually a succinite (KosmowskaCeranowicz, 1999). Baltic amber, called succinite, contains succinic acid. Only about $3 \%$ of the collected amber belongs to other kinds, like gedanite, stantienite, beckerite, glessyt, goitszyk and zygburgit. Gedanite is more brittle as compared with succinite and it contains less than $3 \%$ of succinic acid. It is almost transparent and yellow. Stantienite from Sambian deposits is a black resin without succinic acid, and beckerite is yellow brown, and it resembles a tree fragment, not a resin. The examined Baltic amber is yellow with orange, brown and red shades.

The amber resin secreted mostly from an amberyielding pine (likely by Pinus succinifera) at air temperature of above $25^{\circ} \mathrm{C}$. In the Paleogene, the amber forest formed a biocoenosis that functioned over several millions of years in a vast region of the former northern European mainland that was characterized by stable subtropical-tropical climates. The resin exudation increases in warm and humid conditions. The largest amount of resin is exuded in forests at a warm subtropical and tropical climate. The sudden warming traced in the Eocene might have caused an enhanced outflow of resin. Pear-shaped amber specimens are indicative of a highly viscous resin secreted at $25^{\circ} \mathrm{C}$. The resin exudation might be also forced by volcanic eruptions in the North Sea area in the Paleogene. 


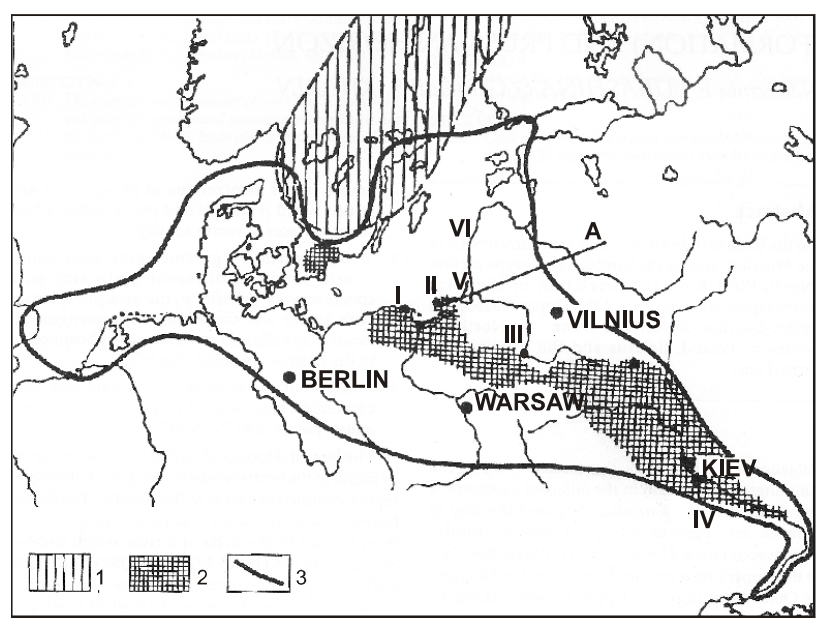

Fig. 1. Areas of distribution of Baltic amber-bearing sediments (after Katinas, 1971). 1 - primary area of amber resins; 2 - amber in Paleogene deposits; 3 - boundary of distribution of re-deposited amber; A - Kaliningrad, I-IV - position of sections (I - Chłopowo, II - Sambia, III - Grodno, IV - Obuchov). V- Curonian lagoon (Lithorina sapropelite), $\mathrm{VI}$ - beaches of East Baltic coast.

Though in the past amber was believed to be completely amorphous, subsequent X-ray diffraction studies have revealed crystalline components in some fossil resins. The infrared spectrum of succinite is reported by Koller et al. (1997).

Data on stable isotopes (H, C, S) may help to solve problems like formation temperature, environmental conditions and origin of the Baltic amber. The first results of $\mathrm{H}, \mathrm{C}$ and $\mathrm{S}$ analyses were obtained for three different varieties of Baltic amber (succinite) from the Sambian Peninsula in 2007. The study by Gaigalas et al. (2007) suggested that the Baltic amber may be a new intercomparison material for carbon stable isotope determination for its isotopic homogeneity and availability. In 2007, we had already obtained $\delta^{13} \mathrm{C}$ results for three Baltic amber samples: The $\delta^{13} \mathrm{C}$ of sample No. 1 (honey shade) was $-22.86 \%$, sample No. 2 (red shade) was $-22.90 \%$ and sample No. 3 (striped yellow with red shade) was $-22.96 \%$ vs. VPDB. It is interesting to note that the $\delta^{13} \mathrm{C}$ obtained are nearly identical. Therefore the Baltic amber is considered an excellent material for the new carbon isotope standard for its homogeneity and ease of $\mathrm{CO}_{2}$ preparation.

In 2008, the stable isotope analysis of nine new amber samples were made at Maria Curie-Skłodowska University in Lublin, Poland. In this paper we describe and discuss all the isotope data obtained so far.

\section{MATERIALS AND METHODS}

A brief sample description is given in Table 1. The samples No. 6 - No. 12 were collected from in situ Eocene deposits (Fig. 2) of the Sambian quarry in the Kaliningrad district of Russia (Fig. 1). The samples No. 4 and No. 5 were resedimented during the Lithorina stage of Baltic Sea evolution in the Holocene. It was collected from the Lithorina mud in the Curonian lagoon near Juodkrante, Lithuania.
Table 1. List of examined amber samples.

\begin{tabular}{ll}
\hline $\begin{array}{l}\text { Sample } \\
\text { No. }\end{array}$ & \multicolumn{1}{c}{ Description } \\
\hline 4 & $\begin{array}{l}\text { Baltic amber, honey-yellow in color, not bright, resedi- } \\
\text { mented, from Lithorina mud, Juodkrante, Curonian lagoon }\end{array}$ \\
5 & $\begin{array}{l}\text { Baltic amber, honey, bright, resedimented, from Lithorina } \\
\text { mud, Juodkrantè, Curonian lagoon }\end{array}$ \\
6 & $\begin{array}{l}\text { Baltic amber, crimson (dark red), not bright, from Eocene } \\
\text { deposits of Sambian quarry }\end{array}$ \\
7 & $\begin{array}{l}\text { Baltic amber, crimson (dark red), not bright, from Eocene } \\
\text { deposits of Sambian quarry }\end{array}$ \\
8 & $\begin{array}{l}\text { Baltic amber, honey, bright, from Eocene deposits of } \\
\text { Sambian quarry, 6 separate pieces (from 8-1 to 8-6) }\end{array}$ \\
9 & $\begin{array}{l}\text { Baltic amber, honey, bright, from Eocene deposits of } \\
\text { Sambian quarry } \\
\text { Baltic amber with weathered crust, dark honey, 2 pieces } \\
\text { (10-1, 10-2) from Eocene deposits of Sambian quarry }\end{array}$ \\
10 & $\begin{array}{l}\text { Baltic amber, yellow, from Eocene deposits of Sambian } \\
\text { quarry }\end{array}$ \\
12 & $\begin{array}{l}\text { Baltic amber with weathered crust, yellow, from Eocene } \\
\text { deposits of Sambian quarry }\end{array}$ \\
\hline
\end{tabular}

Sulphur for isotope analysis was extracted from the amber samples by the Parr bomb method in the form of $\mathrm{SO}_{4}^{2-}$ ion, which subsequently was precipitated as $\mathrm{BaSO}_{4}$, and finally sulphur was converted to $\mathrm{SO}_{2}$ from the barium sulphate by its thermal decomposition (Halas and Szaran, 2001). The isotopic composition of sulphur was analysed on dual inlet and triple collector mass spectrometer on $\mathrm{SO}_{2}$ gas with precision of $0.05 \%$.

Carbon isotope analysis was performed on $\mathrm{CO}_{2}$ gas on a dual inlet and triple collector mass spectrometer. $\mathrm{CO}_{2}$ was prepared by oxidation with a stoichiometric excess of $\mathrm{Cu}_{2} \mathrm{O}$ reagent in sealed borosilicate glass ampoules kept overnight in furnace at $550^{\circ} \mathrm{C}$. Standard uncertainty of $\delta^{13} \mathrm{C}$ value determined from repeated analyses was $0.06 \%$.

The samples for $\delta \mathrm{D}$ analysis were prepared in the Lublin Laboratory to water by $\mathrm{CuO}$-oxidation at $550^{\circ} \mathrm{C}$ (overnight) in sealed borosilicate glass ampoules, and then $5 \mu \mathrm{L}$ water aliquots were converted to $\mathrm{H}_{2}$ gas by the Zn-reduction method (Coleman et al., 1982). Lublin water standard with $\delta \mathrm{D}=-70 \%$ was also prepared to $\mathrm{H}_{2}$ gas for normalization of $\delta \mathrm{D}$ results to the VSMOW scale. Sealed glass ampoules with $\mathrm{H}_{2}$ gas were sent to the AGH Kraków Laboratory (prof. K. Różański).

\section{RESULTS}

Delta ${ }^{13} \mathrm{C}$ vs. VPDB of the next nine samples are given in Table 2. These results confirm the conclusion that Baltic amber may be considered as a good material for a new carbon isotope standard.

In 2007 , we obtained $\delta^{34} \mathrm{~S}=-12.1 \%$ vs. VCDT standard for amber No. 2 only. The other 2 samples contained much lower quantity of organic sulphur. This first result was surprisingly low. Analytical error of $\delta^{34} \mathrm{~S}$ is large, ca. $0.2 \%$, because samples contained a very small amount of $\mathrm{S}$. The low sulphur content is preferred if we consider amber as the $\delta^{13} \mathrm{C}$ standard.

The results of sulphur isotope analysis are presented in Table 2. Sample No. 11 was not analyzed due to low S 


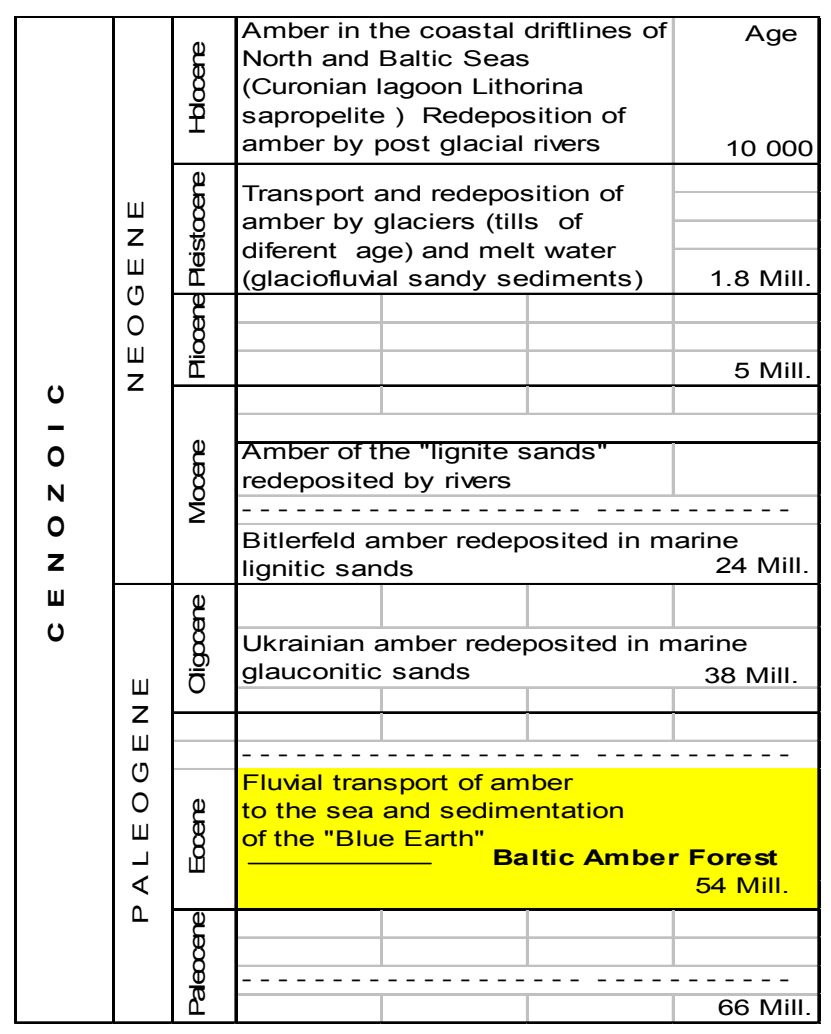

Fig. 2. History of Baltic amber in Cenozoic stratigraphical division (Weitschat, Wichard, 2002).

concentration. The sample No. 12 was subjected to the double prepartion procedure, but in both cases, the result was surprisingly negative.

The first results of deuterium analysis on three our amber samples were received from the AGH Kraków Laboratory in 2007 (Table 2).

\section{DISCUSSION}

The results reflect a low $\delta \mathrm{D}$ of environmental water precipitated in a cold continental climate and the isotope fractionation between water available for the pine tree and the organic compounds produced in its tissues. The results are highly negative. The cellulose-water (environmental) fractionation, averaging ca. $-20 \%$, is known from literature (Epstein et al., 1976). Assuming the similar fractionation for amber, we must conclude that the examined amber may record climate conditions resembling the Arctic area today.

Ambers may be considered as archive (or proxy), which is much better than cellulose because it can record climate conditions over longer time span. The time of amber formation reaches many millions years ago. As it was already mentioned, the Baltic amber is a fossil tree resin that has achieved a stable state through the loss of volatile constituents and the chemical alteration after burial in the ground. The results of $\delta \mathrm{D}$ investigation of the Baltic amber samples also reflect the processes of diagenesis and metagenesis of resins and formation of buried amber, for which the action of Pleistocene Ice covers in arctic environments was important. In another case, the polymerization of resins and formation of fossil
Table 2. Delta values of all the investigated amber samples.

\begin{tabular}{lccc}
\hline Sample No. & $\delta \mathrm{D}(\%)$ & $\boldsymbol{\delta}^{13} \mathbf{C}(\%)$ & $\boldsymbol{\delta}^{34} \mathbf{S}(\%)$ \\
\hline 1 & $-210 \pm 2$ & -22.86 & n. a. \\
2 & $-213 \pm 2$ & -22.90 & -12.1 \\
3 & $-171 \pm 3$ & -22.96 & n. a. \\
4 & n.a. & -22.80 & 4.6 \\
5 & n.a. & -21.40 & -2.9 \\
6 & n.a. & -23.21 & -6.2 \\
7 & n.a. & -22.59 & 0.0 \\
8 & n.a. & -22.75 & -8.9 \\
9 & n.a. & -23.36 & -5.2 \\
10 & n.a. & -22.71 & -5.6 \\
11 & n.a. & -22.99 & n. a. \\
12 & n.a. & -21.93 & $-27.3,-28.7$ \\
\hline NOTE: n. a. $=$ not analysed & &
\end{tabular}

NOTE: n. a. = not analysed

amber underwent at lower temperatures in underground environment. There are more questions regarding the interpretation of received results.

Palaeoclimatic data show that the Late Mesozoic and Paleogene were characterized by very warm climate extending into high paleolatitudes, and subtropicaltropical life forms were spread over a very large area in the Eocene (Weitschat and Wichard, 2002). The "amber forest" encompassed genera and families restricted to the subtropic or tropic areas.

Temperature curves, based on oxygen isotope measurements of carbonates in sedimentary rocks, show regional fluctuations of Cenozoic ocean temperatures. At the end of the Eocene, about 40 million years ago, the plate-tectonic events triggered a drastic global cooling. For this reason the flora and fauna preserved in Baltic amber became a "curious mixture of temperate, subtropical and tropical life forms" (Weitschat and Wichard, 2002; Kosmowska-Ceranowicz, 1999).

\section{CONCLUSION}

Based on this study, the following stages of amber formation (genesis) can be distinguished: (1) Flow of resins from Pinus succinifera (pine). (2) Transport of resins by streams to river delta and marine environments. (3) Accumulation and burial of resins in sediments. (4) Transformation of resins into fossil amber (diagenesis). (5) Deep transformation of amber in the processes of katagenesis and metagenesis. (6) Weathering of amber in surficial conditions.

The isotope ratio of carbon reflects subtropical and tropical climate conditions of resin flow from Pinus trees. The $\delta \mathrm{D}$ values reflect transformation of resins (polymerization) into fossil amber (diagenesis, catagenesis, metagenesis) in burial conditions at low temperatures. Also, during Pleistocene time these deposits were covered by ice sheets several times (Arctic conditions).

Our research is rather new and intriguing, hence it should be continued.

\section{ACNOWLEDGEMENT}

We thank to Professor Kazimierz Różański and his co-workers for performing $\mathrm{D} / \mathrm{H}$ analysis of $\mathrm{H}_{2}$ gas sam- 
ples. The final form of this paper we owe to the reviewers' comments by Professor Teresa Madeyska and Docent Agnieszka Gałuszka.

\section{REFERENCES}

Coleman ML, Shepherd TJ, Durham JJ, Rouse JE and Moore R, 1982. Reduction of water with zinc for hydrogen isotope analysis. Analytical Chemistry 54(6): 993-995, DOI 10.1021/ac00243a035.

Epstein S, Yapp CJ and Hall JH, 1976. The determination of the D/H ratio of non-exchangeable hydrogen in cellulose extracted from aquatic and land plants. Earth and Planetary Science Letters 30(2): 241-251, DOI 10.1016/0012-821X(76)90251-X.

Gaigalas A, Halas S and Trembaczowski A, 2007. Isotope compositin $(\mathrm{H}, \mathrm{C}, \mathrm{S})$ of Baltic amber: a new standard proposal for stable carbon isotope analysis. Abstracts \& Programme, 9th International Conference "Methods of Absolute Chronology" 25-27th April 2007, Gliwice, Poland: 35.

Halas S and Szaran J, 2001. Improved thermal decomposition of sulfates to $\mathrm{SO}_{2}$ and mass spectrometric determination of $\delta^{34} \mathrm{~S}$ of IAEA SO-5, IAEA SO-6 and NBS-127 sulfate standards. Rapid Communications in Mass Spectrometry 15(17): 1618-1620, DOI $10.1002 / \mathrm{rcm} .416$
Kasiński JR and Tołkanowicz E, 1999. Amber in the Northern Lublin Region - Origin and Occurrence. Investigations into amber. Proceedings of the International Interdisciplinary Symposium: Baltic Amber and other Fossil Resins, Gdańsk 2-6 September 1997: 4151.

Katinas V, 1971. Amber and amber-bearing deposits of the Southern Pribaltic. "Mintis", Vilnius: 156pp (in Russian).

Koller J, Baumer B and Baumer U, 1997. Die Untersuchung von Bernstein, Bernsteinölen und Bernsteinlacken. Metalla (Sonderheft) 66: 85-102.

Kosmowska-Ceranowicz B, Ed., 1999. Investigations into amber. Proceedings of the International Interdisciplinary Symposium: Baltic Amber and other Fossil Resins, Gdańsk 2-6 September 1997: 288pp.

Kosmowska-Ceranowicz B, Ed., 2005. Bursztyn - poglądy, opinie (Amber - views, opinions). Materialy z seminariów Amberif 1994 2004: 231.

Kosmowska-Ceranowicz B. 2006. Polska, opowieść o bursztynie. (Poland, The story of Amber). Sport i Turystyka, Muza SA: $120 \mathrm{pp}$.

Lukashina N and Kharin G, 1999. Criteria for the recognition of the Prussian suite (formation) and Prussian horizon. In: KosmowskaCeranowicz B, Ed., 1999, Investigations into amber: 27-32.

Weitschat W and Wichard W, 2002. Atlas of Plants and Animals in Baltic Amber. Verlag Dr. Friedrich Pfeil. München: 256pp. 